ERIA - DP - 2011- 08

ERIA Discussion Paper Series

\title{
Impacts of Incoming Knowledge on Product Innovation: Technology Transfer in Auto-related Industries in Developing Economies
}

\author{
Tomohiro MACHIKITA* ${ }^{*}$ \\ Institute of Developing Economies, Inter-disciplinary Studies Center, Japan \\ Yasushi UEKI \\ Institute of Developing Economies, Bangkok Research Center, Thailand
}

November 2011

\begin{abstract}
This paper studies two questions on the role of networked sources of knowledge influential to product innovation. First: What is the extent of technology transferred through vertical linkages and public-private alliances, including university-industry linkages, in the phase of product improvement and development? Second: What types of knowledge are transferred from external technology sources? In a sample of ASEAN firms' self-reported partner data restricted to automotive related industries, we found that direct linkages with MNC customers in foreign countries resulted in a lower propensity of product innovation. Indeed, incoming knowledge from MNC customers relating to the management of quality of existing products especially explained the lower propensity of product innovation. We also found that production linkages with MNC suppliers in foreign countries resulted in a higher propensity of product innovation. Incoming knowledge from MNC suppliers about quality controls explained a lower propensity of product innovation. These findings empirically indicate that networked sources of knowledge have a significant influence trade-off between maintaining existing operations and developing new products. The impacts of public-private alliances on innovation are sizable compared with the impacts of vertical linkages. Public-private alliances and vertical linkages offer knowledge with different effects on product innovation.

Keywords.: Innovation; Technology transfer; Incoming knowledge; Supply chains; Alliance JEL Classification: D83; 014; O32; R12

\footnotetext{
* The authors are especially grateful for the numerous inputs from, and discussions with, Markus Berliant, Christian Fons-Rosen, Mai Fujita, Masahisa Fujita, Patarapong Intarakumnerd, Fukunari Kimura, Satoru Kumagai, Jacques Mairesse, Yukichi Mano, Pierre Mohnen, Dionisius Ardiyanto Narjoko, Keijiro Otsuka, Sothea Oum, Rajah Rasiah, Yuri Sato, Hiro Tatsumoto, Masatsugu Tsuji, Tsuyoshi Tsuru, So Umezaki, Mariko Watanabe, and Tatsufumi Yamagata in the early stages of this project. It could not have been carried out without cooperation from the Center for Strategic and International Studies (CSIS) of Indonesia, the Philippine Institute for Development Studies (PIDS), National Statistical Office (NSO), the Sirindhorn International Institute of Technology (SIIT), Thammasat University of Thailand, and the Institute for Industry Policy and Strategy (IPSI), Ministry of Industry and Trade of Vietnam. We are responsible for any errors that may remain.

$\dagger$ Institute of Developing Economies, Inter-disciplinary Studies Center, Japan External Trade Organization (IDE-JETRO), 3-2-2 Mihama Wakaba Chiba 2618545, Japan. Tel: +81-43-299-9758. Fax: +81-43-299-9763. Email: machi@ide.go.jp

* Institute of Developing Economies, Bangkok Research Center, Japan External Trade Organization, 16F Nantawan Building, 161 Rajdamri Road, Bangkok 10330, Thailand. Email: yasushi_ueki@ide-jetro.org.
} 


\section{Introduction}

Economic linkage is fundamentally concerned with explaining differences in the performance and capabilities of firms. Economic linkages with customers, suppliers, public organizations and universities have been seen as important drivers of industrial upgrading for firms in developing economies. Furthermore, understanding why some firms with specific types of economic linkage succeed while others fail (or choose other ways) is a central question. Some firms can utilize and internalize incoming knowledge spilled over from partners. External linkages have therefore also been considered as an important source of knowledge especially for firms without competitive internal knowledge.

The aim of this paper is to understand which types of economic linkage play an important role of achieving product innovation. This is the first question. Since product innovation has been considered as one of the important determinants of productivity growth (see Syverson 2011), this paper tackles the causes of product innovation with special attention to external knowledge sources. Second, if we can get a deeper insight into the relationship between external linkages and product innovation, we may ask how each type of linkage helps firms to achieve product innovation. In the second question, we will explain the mechanism for generating the impact of specific types of technology transfer on product innovation. These two questions give us an opportunity to evaluate who transfers technologies to whom, why, and how important the impacts on innovation technology are. In short, this paper tries to show the extent of the impact of vertical linkages, such as (domestic/ international) supply chains, and horizontal linkages with non competitors, such as public organizations and universities.

There are many previous studies on the impacts of technology transfer on innovations through different types of linkages. Cassiman and Veugelers $(2002,2006)$, Vega Jurad et al. (2008), Frenz and Ietto-Gilles (2009), and Machikita and Ueki (2011a) clearly demonstrate that the combination of internal and external sources of knowledge is valuable for firm-level innovation. These previous works suggest that complementarities between these two different sources play an important role in 
industrial upgrading. Unfortunately, this line of research focused on comparing the impacts of different sources of knowledge on innovation. It is natural to think that different sources bring different types of knowledge into firms. However the previous research has not provided evidence on what types of information were transferred. To understand technology transfer in detail, we have to make a firm-level dataset including exact information on incoming and outgoing knowledge types. ${ }^{1}$

To understand mechanisms for generating the positive effects of external sources on product innovation, it is useful to apply the main concept of interactive learning through user/producer interactions that was introduced most notably by Lundvall $(1985,1988)$ and which led to seminal contributions on user-driven innovation by von Hippel (1986, 1988, 2005). These classic works on interactive learning have highlighted Polanyi's argument: the tacit dimension of knowledge exchanges may limit the extent of tradability of knowledge (Polanyi 1966, 2009). Therefore, face-to-face interactions are indispensable to knowledge transfer (Machikita and Ueki 2011b). Transferred technologies lead to dynamic capabilities (Teece 2009). This paper adopts the concept of interactive learning as a theoretical foundation supporting the effectiveness of knowledge spillovers among firms in upstream and downstream relations.

Among several channels of technology transfer, vertical linkages have been emphasized in the empirical research into the knowledge transmission mechanism between upstream and downstream firms, in the context of developing and emerging economies. For example, Aitken and Harrison (1999), Javorcik (2004) and Blalock and Gertler (2008) find backward linkage impacts in terms of productivity growth for local suppliers from MNC customers by using the share of MNCs in downstream sectors as an explanatory variable. ${ }^{2} \quad$ Especially, Blalock and Gertler (2008) give the interpretation that there is a sizable technology transfer to upstream firms from downstream MNCs behind empirical estimates of the relationship between the share of MNCs in downstream firms and productivity growth. Even so, Blalock and Gertler

\footnotetext{
1 In the setting of the agricultural household model in development economics, Conley and Udry (2010) establishes a farmer's self-reported informational neighbor dataset to detect direct and indirect information flows among farmers.

2 The literature on global value chains (GVCs) has argued that in the context of upstream and downstream relationships in developing economies, downstream MNCs, or so called "lead firms", are likely to organize global supply chains and control knowledge spillovers from them to local suppliers (see Intarakumnerd and Fujita 2008).
} 
(2008) lacks direct evidence that precisely captures the knowledge transmission mechanism through interaction among local producers and MNCs, and we cannot infer who transfers technologies to whom. Our paper attempts to fill the gap utilizing firm's self-reported data on customer-supplier relationships. ${ }^{3}$

Horizontal linkages, especially linkages between industries and universities/ public research institutes, are other channels for technology spillover that have significant impacts on innovation and industrial development. Seminal works by Mansfield (1991 and 1998) provide an overview of the conditions and empirical evidence of university and industry linkages (UILs). Bercovitz and Feldman (2006, 2007, 2008, and 2011) present the evidence and a theoretical background to explain the importance of industrial upgrading in developed economies. Other recent works from developed countries, including East Asia, also suggest positive spillovers from university to industry. ${ }^{4}$ Contrary to the cases of developed economies, university capacity is not high and firms and industries in South East Asia do not seem to expect local UILs. We need, however, more empirical evidence of UILs in developing economies based on rigorous methods and detailed datasets, including information on the connections between firms and local universities in South East Asia. This paper provides concrete evidence by using a dataset of firms' self-reported alliances with Universities and local public (business) organizations.

For further empirical exploration of interactive learning and innovation, this paper proposes following two approaches to explain the differences in firm upgrading. First, we propose using data reported by firms on their partners, and detailed information on sources of incoming knowledge (Cassiman and Veugelers 2002, 2006). Second, we propose a simple theory explicitly assuming that incoming knowledge spillovers influence the trade-off between inaction (i.e. choosing the status quo) and upgrading with significant cost (see Berliant and Fujita, 2008, 2009). We combine the unique dataset from upstream-downstream relations with the theoretical framework to estimate the impacts of external linkages on firm-level product innovation. Our approach is useful in interpreting significant and sizable differences in firm-level industrial

\footnotetext{
3 An exceptional case is found in Hortacsu and Syverson (2009) which infers the existence of managerial knowledge transfer across two plants based on a shipment database.

4 See Salter and Martin (2001), Monjon and Waelbroeck (2003), Laursen and Salter (2004), Bekkers and Freitas (2008), Kroll and Liefner (2008), and Eom and Lee (2010).
} 
upgrading across firms with and without specific alliances.

In a sample dataset of firms' self-reported partners, including automotive related industries in ASEAN, we found the following three empirical results. First, greater knowledge sharing on the part of an MNC customer in a foreign country resulted in a lower propensity of product innovation. Accompanying this, we also found that incoming knowledge from an MNC customer about claim management relating to existing products especially explained the lower propensity for product innovation for ASEAN firms. Second, we also found that production linkages with an MNC supplier in a foreign country resulted in a higher propensity of product innovation. In addition to this, we found that incoming knowledge from an MNC supplier about quality controls explained the lower propensity of product innovation. Finally, a strategic alliance with a public organization, local business organization, or university also plays an important role in product innovation. The innovation impacts of such alliances are as sizable as the innovation impacts of vertical linkages.

In Section two below, we seek to compare vertical linkages with horizontal alliances with public organizations and universities. This study is motivated by findings regarding firm-level perception of the production and investment climates across MNCs and local enterprises. Especially, our understanding of the firm-level perception of the local investment climate made us to focus on comparisons between vertical linkages and alliances with public organizations or universities. The empirical evidence in this paper is shown in Sections three and four. We present our empirical analysis based on our unique dataset of firms' self-reported partners, including the type of vertical production partners (upstream supplier, buyer, and downstream customer) as well as horizontal alliance partners (public organizations and universities) in Section 3. The firm-level dataset suggests that backward linkages with foreign customers negatively affect the propensity of product innovation. Linkages with foreign suppliers and buyers have positive impacts on achieving product innovation. Alliances with public organizations and universities positively affect product innovation. In Section 4, this paper also demonstrates the specific mechanism behind the above results by using information about incoming knowledge spillovers from production partners, public organizations, and universities. Section 5 concludes. 


\section{Motivating facts: local and global obstacles for upgrading}

To show our motivation for this study, we provide some simple facts about ASEAN firms based on firm-level survey by the authors and collaborators and follow-up interviews with managers in 2008. In our 2008 survey of firms in Indonesia, the Philippines, Thailand, and Vietnam, we asked for a manager's perception of the obstacles they faced in the areas of innovation and upgrading. The list given includes obstacles related to high tariffs, inadequate support from the R\&D services industry, labor market rigidity, and insufficient access to public support organizations. In addition, the managers rated the seriousness of each of the different effects on a scale of 1-5, namely: (1) Not serious; (2) Not very serious; (3) Not sure; (4) Somewhat serious; and (5) Very serious. Ideally, if there were no market frictions, managers could adjust their resources to the optimal level and thereby achieve the optimal level of innovation. If this were true, however, the expected response of the managers should have been (1) or "Not serious." But since some bottlenecks usually exist in production, procurement, distribution, and market in developing economies, the manager's response would normally reflect the existence of misallocations, maladjustments, or malpractice in the integration of inputs and resources. This is one source of the large productivity dispersion in developing economies, where labor and capital cannot reallocate smoothly from unproductive to productive firms (See Hsieh and Klenow 2009).

We therefore hypothesize that managerial beliefs are driven by the difference between the optimal investment level for achieving innovation and the current intensity of obstacles for achieving innovation. This idea follows Bresnahan, et al. (2002). According to this previous contribution on complementarities in workplace management practice, managerial perceptions about computer effects on changes in work organization would suggest causality, since a manager's perception of causality could be reflected in the difference between optimal and current investment level in IT, human capital, and changes in work organization. Dependent dummy variables are based on the managerial evaluation of obstacles for innovation and upgrading. The rating equals to one if managers rate each obstacle as "Somewhat Serious" or "Very Serious" and is zero otherwise. Independent variables include the firm's characteristics, that is, linkages and capital structure which reflect information sources 
and country characteristics.

We can draw three facts from Tables 1 and 2 which show that there is a clear difference in managerial perception of obstacles across firm and country characteristics. First, Column 1 of Table 1 shows the coefficient for Vietnam to be .446 , with a standard error of .034 when we take the difference in the variety of linkages into account. Compared to firms in Thailand, Vietnamese firms, on average, feel that higher tariffs on equipments and materials are bottlenecks for innovation and upgrading. The variety of linkages also affects the managerial evaluation. The coefficient for the number of production linkages (number of intellectual linkages) is .017 (.029), with a standard error of .005 (.009). Firms with many types of linkages feel that higher tariffs are bottlenecks for innovation and upgrading. As reported in a previous section, firms with many linkages also achieve many types of innovations and a have a higher possibility of introducing market-based innovations. The target level of innovations and their intensity for such firms are usually higher and deeper compared to firms with fewer linkages. This result suggests the need for a policy of reducing tariffs to encourage innovation and upgrading, especially for Vietnam.

Table 1. Obstacles for Multinationals and Policy Needs at National Level

\begin{tabular}{|c|c|c|c|c|}
\hline Probit (Marginal Effects) & (1) & (2) & (3) & (4) \\
\hline $\begin{array}{c}\text { Dependent variables: Very Serious } \\
\text { or Somewhat Serious (1) vs Others } \\
(0)\end{array}$ & $\begin{array}{l}\text { High tariffs on } \\
\text { equipments and } \\
\text { materials } \\
\text { necessary for } \\
\text { innovation }\end{array}$ & $\begin{array}{c}\text { No R\&D } \\
\text { supporting } \\
\text { industry such as } \\
\text { consulting and } \\
\text { financing }\end{array}$ & $\begin{array}{l}\text { Price of R\&D } \\
\text { support services } \\
\text { is high }\end{array}$ & $\begin{array}{l}\text { Protection of } \\
\text { intellectual } \\
\text { property right } \\
\text { (IPR) is not } \\
\text { sufficient }\end{array}$ \\
\hline \multirow[t]{2}{*}{ Multinational Enterprises } & 0.023 & 0.074 & $0.130^{*}$ & $0.147 *$ \\
\hline & {$[0.055]$} & {$[0.058]$} & {$[0.055]$} & {$[0.060]$} \\
\hline Number of Linkages & $\begin{array}{l}0.012 * * \\
{[0.003]}\end{array}$ & $\begin{array}{c}0.007+ \\
{[0.004]}\end{array}$ & $\begin{array}{c}0 \\
{[0.003]}\end{array}$ & $\begin{array}{c}0.018 * * \\
{[0.004]}\end{array}$ \\
\hline \multirow[t]{2}{*}{ Age } & 0.001 & 0.002 & 0.003 & -0.002 \\
\hline & {$[0.002]$} & {$[0.002]$} & {$[0.002]$} & {$[0.002]$} \\
\hline \multirow[t]{2}{*}{ Full-time Employees } & $-0.000 *$ & $-0.000 *$ & 0 & $-0.000 * *$ \\
\hline & {$[0.000]$} & {$[0.000]$} & {$[0.000]$} & {$[0.000]$} \\
\hline \multirow[t]{2}{*}{ Indonesia } & $0.433 * *$ & $0.426 * *$ & $0.231 * *$ & $0.499 * *$ \\
\hline & {$[0.036]$} & {$[0.054]$} & {$[0.062]$} & {$[0.050]$} \\
\hline \multirow[t]{2}{*}{ Philippines } & $0.324 * *$ & $0.230 * *$ & 0.113 & $0.368 * *$ \\
\hline & {$[0.060]$} & {$[0.081]$} & [0.079] & {$[0.080]$} \\
\hline \multirow[t]{2}{*}{ Vietnam } & $0.446 * *$ & $0.392 * *$ & $0.310 * *$ & $0.581 * *$ \\
\hline & {$[0.034]$} & {$[0.059]$} & {$[0.061]$} & {$[0.038]$} \\
\hline Observations & 587 & 587 & 587 & 587 \\
\hline
\end{tabular}


Notes:

Robust standard errors in brackets.

+ significant at $10 \% ; *$ significant at $5 \% ; * *$ significant at $1 \%$

Reference country is Thailand.

Source: ERIA Establishment Survey, 2008.

Second, we turn to another policy need at the national level, namely the price and existence of R\&D support (Column 2 and 3 of Table 1) and Intellectual Property Rights (IPR) policy (Column 4 of Table 1). The coefficient for multinationals is positive and significant for ratings indicating serious country-wide market obstacles. These obstacles are not appropriate at the local level and should be targeted at the national level. It is beneficial, especially for inviting and improving multinational activities, to implement a policy of "wheel-greasing" or addressing the problems of the availability of less expensive R\&D support and imposing limitations on copying.

Finally, we also show managerial perception of the production and investment climate at the local level, namely: (1) familiarity with local public support program(s); (2) addressing any mismatch with public support program(s); (3) local public support in providing training courses or testing facilities; and (4) geographic proximity to local university and/or public research institute. Table 2 shows that firms in Indonesia, the Philippines, and Vietnam also show sizable obstacles for accessing local alliances. The coefficient for multinationals is negative and significant, indicating serious local level constraints. These results suggest that local and joint venture firms are not familiar with local public support program(s), and that public support is not designed appropriately for local firms. The local production and investment climate seems not to favor local firms wishing to access and utilize public support from local business organizations, chambers of commerce, local universities, or public research institutes. There is therefore much room for improvement of the situation regarding innovation and upgrading for local firms to maintain local public policy. 
Table 2: Obstacles for Local Firms and Policy Needs at Local Level

\begin{tabular}{|c|c|c|c|c|}
\hline Probit (Marginal Effects) & (1) & (2) & (3) & (4) \\
\hline $\begin{array}{l}\text { Dependent variables: Very } \\
\text { Serious or Somewhat Serious (1) } \\
\text { vs Others }(0)\end{array}$ & $\begin{array}{l}\text { My } \\
\text { establishment } \\
\text { is not familiar } \\
\text { with public } \\
\text { support } \\
\text { programs and } \\
\text { procedures to } \\
\text { apply for } \\
\text { support } \\
\text { measures }\end{array}$ & $\begin{array}{l}\text { Public support } \\
\text { programs are } \\
\text { not designed } \\
\text { appropriately } \\
\text { for innovation }\end{array}$ & $\begin{array}{l}\text { No business } \\
\text { organization or } \\
\text { chamber of } \\
\text { commerce } \\
\text { which can } \\
\text { provide } \\
\text { training } \\
\text { courses, } \\
\text { seminar or } \\
\text { testing } \\
\text { facilities }\end{array}$ & $\begin{array}{l}\text { No university } \\
\text { or public } \\
\text { institute in the } \\
\text { neighborhood }\end{array}$ \\
\hline \multirow[t]{2}{*}{ Multinational Enterprises } & $-0.289 * *$ & $-0.147 * *$ & $-0.201 * *$ & $-0.109 *$ \\
\hline & {$[0.050]$} & {$[0.054]$} & {$[0.050]$} & {$[0.045]$} \\
\hline \multirow[t]{2}{*}{ Number of Linkages } & $0.012 * *$ & $0.012 * *$ & $0.007 *$ & $0.008 * *$ \\
\hline & {$[0.003]$} & {$[0.003]$} & {$[0.003]$} & {$[0.003]$} \\
\hline \multirow[t]{2}{*}{ Age } & $0.004^{*}$ & 0.002 & -0.003 & 0 \\
\hline & {$[0.002]$} & {$[0.002]$} & {$[0.002]$} & {$[0.002]$} \\
\hline \multirow[t]{2}{*}{ Full-time Employees } & 0 & 0 & 0 & 0 \\
\hline & {$[0.000]$} & {$[0.000]$} & {$[0.000]$} & {$[0.000]$} \\
\hline \multirow[t]{2}{*}{ Indonesia } & $0.361 * *$ & $0.444 * *$ & $0.498 * *$ & $0.357 * *$ \\
\hline & {$[0.074]$} & {$[0.069]$} & {$[0.066]$} & {$[0.073]$} \\
\hline \multirow[t]{2}{*}{ Philippines } & $0.386 * *$ & $0.368 * *$ & $0.413 * *$ & $0.215^{* *}$ \\
\hline & {$[0.081]$} & {$[0.082]$} & {$[0.081]$} & {$[0.077]$} \\
\hline \multirow[t]{2}{*}{ Vietnam } & $0.399 * *$ & $0.169+$ & 0.126 & 0.135 \\
\hline & {$[0.077]$} & [0.089] & [0.093] & [0.083] \\
\hline Observations & 587 & 587 & 587 & 587 \\
\hline
\end{tabular}

Notes:

Robust standard errors in brackets.

+ significant at $10 \%$; $*$ significant at $5 \%$; ** significant at $1 \%$

Reference country is Thailand.

Source: ERIA Establishment Survey, 2008.

In summary, MNCs are likely to answer that national level R\&D support is weak in ASEAN (Table 1) while local enterprises are likely to answer that access to the local level public support is difficult and that the support is weak for local firms (Table 2). Both tables therefore show that MNCs and local enterprises have different managerial perceptions of national and local level support. Based on these findings, we propose to estimate whether linkages and alliances affect firm-level innovation and to explain how firms absorb incoming knowledge spillovers from each linkage and alliance. Since empirical analysis in the next section shows the extent of external linkages, and their 
effectiveness in industry upgrading, and shows specific channels of technology transfer, it will provide evidence to guide local policy.

\section{Empirical analysis}

In 2010, the authors conducted a firm-level survey of 794 manufacturing firms in four countries from ASEAN: Indonesia (Jabodetabek area), the Philippines (Carabarzon area), Thailand (Greater Bangkok area), and Vietnam (Hanoi and Ho Chi Minh City). We gather information on innovation, external linkages (including vertical production networks and strategic alliances with public organizations or universities), and internal research \& development and firm size to capture absorptive capacity.

The focal industry in this paper is automobile manufacture and auto parts suppliers, following Dyer $(1996,1997)$. A car is well-known to be most complicated manufacturing good and requires numerous types of parts and components from different specialized suppliers in different industries. A car is made by not only automotive suppliers from metal products but also other automotive suppliers, from electrical machinery, cable (wire) harnesses, front pads and rotors, tires, disk brakes and so on. To cover global supply chains more deeply, we restrict our estimated sample to the following seven industries: (1) Automobile, auto parts; (2) Metal products; (3) Machinery, equipment, tools; (4) Iron, steel; (5) Plastic, rubber products; (6) Chemicals, chemical products; (7) Other electronics, components. Finally, we use less than 300 firms for empirical analysis.

In our survey, we collected not only information on product innovation but also on process innovation. As past research has pointed out, process innovation has many dimensions, from procurement to discovery of a new market or introducing total quality management. This paper focuses on improvement of product and product innovation in order to uncover the straightforward channels of linkages and alliances. In this paper, we define our dependent variable as being one of the following three types: (1) Significant improvement of an existing product; (2) New product based on the existing technologies; (3) New product based on new technologies. The explanatory variable is related to external sources, including both vertical linkages and strategic alliances. To explicitly capture the heterogeneity and desorptive capacity (outgoing knowledge 
spillovers) among vertical linkages and alliances, we recognize ten different types of external source: (1) Buyer or trading company; (2) Local customer; (3) Local supplier; (4) Domestic MNC or Joint Venture customer; (5) Domestic MNC or Joint Ventures supplier; (6) Overseas MNC or Joint Venture customer; (7) Overseas MNC or Joint Venture supplier; (8) Public organization; (9) Local business organization; (10) University or Public Research Institute.

The types of product innovation and the firms' basic characteristics, including their external sources, are summarized in Table 3. The most apparent feature is that there is "quality ladder" relationship between three types of product innovation: (1) Significant improvement of an existing product is prevalent among more than two thirds of sample firms; (2) Introduction of a new product based on the existing technologies is a more difficult task than improvement of product, and is achieved by less than half of firms; (3) Introducing a new product based on new technologies is the most difficult task, only achieved by around $25 \%$ of firms. Table 3 also shows the variety of internal resources and external information sources of auto-related industries. First, firms' self-reported production partners are more important sources than public or non-production organizations. Second, firms' self-reported R\&D activity is prevalent among $50 \%$ of manufacturers in auto-related industries. Third, establishment size varies widely across different categories, from 20-49 employees to 500-999.

Table 3: Summary Statistics

\begin{tabular}{lcccc}
\hline Variable & Mean & Std. Dev. & Min & Max \\
\hline \hline $\begin{array}{l}\text { Dependent variables- product innovation } \\
\text { Significant improvement of an existing product }\end{array}$ & 0.626 & 0.484 & 0 & 1 \\
& & & & \\
New product based on the existing technologies & 0.446 & 0.498 & 0 & 1 \\
New product based on new technologies & 0.252 & 0.435 & 0 & 1 \\
Explanatory variables- external sources & & & & \\
Buyer or trading company & & & & \\
Local customer & 0.453 & 0.498 & 0 & 1 \\
Local supplier & 0.425 & 0.495 & 0 & 1 \\
Domestic MNC/JV customer & 0.332 & 0.471 & 0 & 1 \\
Domestic MNC/JV supplier & 0.310 & 0.463 & 0 & 1 \\
\hline
\end{tabular}




\begin{tabular}{lcccc}
\hline Variable & Mean & Std. Dev. & Min & Max \\
\hline \hline Overseas MNC/JV customer & 0.275 & 0.447 & 0 & 1 \\
Overseas MNC/JV supplier & 0.202 & 0.402 & 0 & 1 \\
Public organization & 0.179 & 0.384 & 0 & 1 \\
Local business organization & 0.172 & 0.378 & 0 & 1 \\
University/ Public Research Institute & 0.082 & 0.275 & 0 & 1 \\
Explanatory variables- firm characteristics & & & & \\
R\&D & & & & \\
100\% locally owned & 0.501 & 0.501 & 0 & 1 \\
Establishment size controls & 0.599 & 0.491 & 0 & 1 \\
$1-19$ persons & & & & \\
20-49 & 0.056 & 0.230 & 0 & 1 \\
50-99 & 0.128 & 0.335 & 0 & 1 \\
$100-199$ & 0.145 & 0.352 & 0 & 1 \\
200-299 & 0.214 & 0.411 & 0 & 1 \\
$300-399$ & 0.152 & 0.359 & 0 & 1 \\
$400-499$ & 0.086 & 0.281 & 0 & 1 \\
$500-999$ & 0.042 & 0.201 & 0 & 1 \\
$1000-1499$ & 0.100 & 0.301 & 0 & 1 \\
$1500-1999$ & 0.028 & 0.165 & 0 & 1 \\
2000- & 0.023 & 0.151 & 0 & 1 \\
\hline Sourc: ERIA Establishment Survey, 2010 & 0.026 & 0.158 & 0 & 1 \\
\hline
\end{tabular}

Source: ERIA Establishment Survey, 2010.

This paper assumes the firm's knowledge production function using the estimated equation and simply regress innovation to the proxy of knowledge flows. Dependent variable $y$ means the binary outcome of product innovation for each firm $i$ which equals to one if each firm achieved product innovation. Explanatory variable $Z$ is a vector signifying more than ten different external sources. We also control firm-level absorptive capacity $x$ and a cross-sectional error term is shown by $u$. To simply regress innovation outcome to covariates, focus is given on the estimated coefficient of $Z$ as the degree of firm-level technology which transfers from incoming knowledge spillovers to product innovation. Our estimated equation is as follows:

$$
\operatorname{Pr}\left(y_{i}=1\right)=\alpha+\beta Z_{i}+\gamma x_{i}+u_{i}
$$


Table 4 presents the regression results on whether and which external sources affect product innovation under controlled firm-level characteristics. Columns 1 to 3 of Table 4 show the marginal effects of Probit estimates: the impact of external sources, including vertical linkages and alliances with public organizations and universities, on significant improvement of existing products, introduction of a new product based on technologies already used by the firm, and introduction of a new product based on technologies new to the firm respectively. Column 1 of Table 4 suggests that the coefficient for an MNC or Joint Venture (hereafter JVs) customer in a foreign country is -0.205 , with a robust standard error of 0.103 . The result means that a firm selling parts and components to MNCs or JVs in foreign countries is likely not to attempt product innovation. Such a producer prefers the "status quo" relationship with its foreign customers rather than to invest in upgrading their product. But the coefficient for MNC or JVs' suppliers in foreign countries is 0.326 , with a robust standard error of 0.064. This result implies that a firm buying intermediate inputs from MNCs or JVs in foreign countries is likely to upgrade their product. This effect is sizable and statistically significant, and overcomes the negative impact in the case where the firm also sells its product to MNCs or JVs located in foreign countries. In short, there is much difference in the impact of external sources between MNC or JV customers and suppliers in foreign countries. Buyers or trading companies also had a positive and significant impact on the improvement of existing products. These results are also robust, even after restricting the estimated sample (not shown here). Alliances with public organizations also positively affect the improvement of existing products.

Column 2 of Table 4 shows the impact of external sources on the market introduction of new products based on existing technologies. This column shows that the coefficient for MNC or JV customers in foreign countries is -0.183 with a robust standard error of 0.101 . This result suggests that a firm selling parts and components to MNCs or JVs in foreign countries is, in general, not likely to introduce new products based on existing technologies. As in Column 1 of Table 4, the coefficient for MNC or JV suppliers in foreign countries is 0.260 with a robust standard error of 0.116 , and thus the linkage with a foreign supplier has a positive impact on product innovation. On the other hand, this column also shows than a linkage with a local supplier has a negative impact on product innovation. Buyers or trading companies play an important role in 
introducing new product based on existing technologies.

Finally, Column 3 of Table 4 shows the results for the introduction of new products based on new technologies. This column shows that the coefficient for MNC or JV customers in foreign countries is -0.062 with a robust standard error of 0.075 . This reveals a negative but not statistically significant impact. The coefficient for MNC or JV suppliers in foreign countries is 0.122 , with a robust standard error of 0.119 . Thus having a foreign supplier results in a positive but not statistically significant impact. The estimated impact of buyers or trading companies is statistically insignificant, but this has similar sign to those in Columns 1 and 2. Alliances with public organizations positively affect the introduction of new products based on new technologies.

Table 4: External sources have different impacts on product innovation

\begin{tabular}{lccc}
\hline \multirow{2}{*}{ Probit (Marginal Effects) } & $(1)$ & $(2)$ & $(3)$ \\
\cline { 2 - 4 } Dependent variables: Yes (1) vs No (0) & $\begin{array}{c}\text { Significant } \\
\text { improvement of an } \\
\text { existing product }\end{array}$ & $\begin{array}{c}\text { New product based } \\
\text { on the existing } \\
\text { technologies }\end{array}$ & $\begin{array}{c}\text { New product } \\
\text { based on new } \\
\text { technologies }\end{array}$ \\
\cline { 2 - 4 } Buyer or trading company & $0.368^{* * *}$ & $0.219^{* * *}$ & 0.076 \\
Local customer & $(0.074)$ & $(0.077)$ & $(0.062)$ \\
Local supplier & -0.038 & 0.039 & -0.063 \\
Domestic MNC/JV customer & $(0.096)$ & $(0.092)$ & $(0.071)$ \\
Domestic MNC/JV supplier & -0.109 & $-0.212^{* *}$ & 0.069 \\
Overseas MNC/JV customer & $(0.094)$ & $(0.091)$ & $(0.084)$ \\
Overseas MNC/JV supplier & -0.095 & 0.042 & 0.004 \\
Public organization & $(0.098)$ & $(0.092)$ & $(0.082)$ \\
Local business organization & 0.080 & 0.040 & -0.023 \\
University/ Public Research Institute & $(0.096)$ & $(0.115)$ & $(0.096)$ \\
R\&D & $-0.205^{* *}$ & $-0.183^{*}$ & -0.062 \\
& $(0.103)$ & $(0.101)$ & $(0.075)$ \\
& $0.326^{* * *}$ & $0.260^{* *}$ & 0.122 \\
& $(0.064)$ & $(0.116)$ & $(0.119)$ \\
& -0.193 & -0.108 & -0.087 \\
& $(0.143)$ & $(0.121)$ & $(0.085)$ \\
& $0.287^{* * *}$ & 0.130 & $0.266^{*}$ \\
& $(0.088)$ & $(0.139)$ & $(0.141)$ \\
& -0.092 & 0.125 & 0.093 \\
& $(0.159)$ & $(0.140)$ & $(0.122)$ \\
& 0.030 & -0.025 & -0.035 \\
& $(0.076)$ & $(0.079)$ & $(0.066)$ \\
\hline
\end{tabular}




\begin{tabular}{|c|c|c|c|}
\hline Probit (Marginal Effects) & (1) & (2) & (3) \\
\hline Dependent variables: Yes (1) vs No (0) & $\begin{array}{c}\text { Significant } \\
\text { Improvement of } \\
\text { an existing product }\end{array}$ & $\begin{array}{l}\text { New product based } \\
\text { on the existing } \\
\text { technologies }\end{array}$ & $\begin{array}{r}\text { New product } \\
\text { based on new } \\
\text { technologies }\end{array}$ \\
\hline \multirow[t]{2}{*}{$100 \%$ locally owned } & -0.003 & 0.004 & 0.064 \\
\hline & $(0.079)$ & $(0.075)$ & $(0.057)$ \\
\hline Country controls & Yes & Yes & Yes \\
\hline Establishment size controls & Yes & Yes & Yes \\
\hline Industry controls & Yes & Yes & Yes \\
\hline $\mathrm{N}$ & 277 & 272 & 271 \\
\hline R2 & 0.317 & 0.136 & 0.175 \\
\hline
\end{tabular}

Source: ERIA Establishment Survey, 2010.

What is the difference in the impacts of external sources between MNCs and local enterprises? To seek the answer to this question, Table 5 demonstrates the result of a similar empirical experiment as Table 4 for MNCs and local suppliers respectively. Table 5 shows the matches between MNC suppliers and their production partners or alliance partners (Columns 1 to 3 ) and matches between local producers and their production partners or alliance partners (Columns 4 to 6). Since Table 4 found that vertical linkages are important for both MNCs and local enterprises, we focus on the coefficients of MNC or JV customers and suppliers so as to understand the consequence of economic transactions with foreign or domestic MNCs. Column 1 of Table 5 shows that MNCs are not likely to improve their existing products if they sold their products to MNCs or JVs in foreign countries. This is not true the case of introducing new products (Columns 2 and 3 of Table 5). On the other hand, Columns 1 and 2 suggest that MNCs are likely to improve products and introduce new products if they bought intermediate inputs from MNCs or JVs in foreign countries.

Local enterprises are not likely to improve existing products if they sell the products to domestic MNCs or JVs (Column 4). But this is not true for local firms in the case of introducing new products (Column 5 and 6). Column 4 also suggests that local enterprises are likely to improve products if they bought intermediate inputs from MNCs or JVs in foreign countries. Alliances with local business organizations have positive and significant impacts for $\mathrm{MNCs}$ and local enterprises in terms of the improvement of existing products, and product innovation. The impact of university-industry linkages is negative for MNCs and positive for local enterprises, but these results are insignificant. 
Table 5: The impacts of external sources on product innovation differ across MNCs and local enterprises

\begin{tabular}{|c|c|c|c|c|c|c|}
\hline \multirow[t]{2}{*}{ Probit (Marginal Effects) } & $(1)$ & $(2)$ & (3) & (4) & $(5)$ & $(6)$ \\
\hline & \multicolumn{3}{|c|}{$\mathrm{MNCs}$} & \multicolumn{3}{|c|}{ Local Enterprises } \\
\hline Dependent variables: Yes (1) vs No (0) & $\begin{array}{l}\text { Significant } \\
\text { improvement of } \\
\text { an existing } \\
\text { product }\end{array}$ & $\begin{array}{l}\text { New product } \\
\text { based on the } \\
\text { existing } \\
\text { technologies }\end{array}$ & $\begin{array}{l}\text { New product } \\
\text { based on new } \\
\text { technologies }\end{array}$ & $\begin{array}{l}\text { Significant } \\
\text { improvement of } \\
\text { an existing } \\
\text { product }\end{array}$ & $\begin{array}{l}\text { New product } \\
\text { based on the } \\
\text { existing } \\
\text { technologies }\end{array}$ & $\begin{array}{l}\text { New product } \\
\text { based on new } \\
\text { technologies }\end{array}$ \\
\hline \multirow[t]{2}{*}{ Buyer or trading company } & $0.449 * *$ & 0.263 & $0.175 * *$ & $0.258 * * *$ & $0.271 * *$ & -0.004 \\
\hline & $(0.182)$ & $(0.163)$ & $(0.071)$ & $(0.077)$ & $(0.109)$ & $(0.077)$ \\
\hline \multirow[t]{2}{*}{ Local customer } & -0.086 & -0.014 & -0.088 & -0.045 & 0.111 & -0.114 \\
\hline & $(0.191)$ & $(0.151)$ & $(0.082)$ & $(0.127)$ & $(0.137)$ & $(0.091)$ \\
\hline \multirow[t]{2}{*}{ Local supplier } & -0.024 & -0.242 & $0.226^{*}$ & -0.192 & $-0.281 * *$ & -0.077 \\
\hline & $(0.163)$ & $(0.158)$ & $(0.126)$ & $(0.136)$ & $(0.129)$ & $(0.094)$ \\
\hline \multirow[t]{2}{*}{ Domestic MNC/JV customer } & -0.140 & 0.193 & 0.103 & $-0.249 *$ & -0.009 & -0.054 \\
\hline & $(0.164)$ & $(0.144)$ & $(0.110)$ & $(0.133)$ & $(0.140)$ & $(0.095)$ \\
\hline \multirow[t]{2}{*}{ Domestic MNC/JV supplier } & 0.024 & -0.134 & $-0.159 * * *$ & 0.115 & 0.109 & 0.220 \\
\hline & $(0.182)$ & $(0.198)$ & $(0.059)$ & $(0.106)$ & $(0.168)$ & $(0.178)$ \\
\hline \multirow[t]{2}{*}{ Overseas MNC/JV customer } & $-0.412 * *$ & -0.269 & -0.037 & -0.021 & -0.160 & -0.088 \\
\hline & $(0.166)$ & $(0.173)$ & $(0.091)$ & $(0.148)$ & $(0.170)$ & $(0.086)$ \\
\hline \multirow[t]{2}{*}{ Overseas MNC/JV supplier } & $0.467 * * *$ & $0.508 * * *$ & 0.244 & $0.269 * * *$ & -0.082 & $-0.135^{*}$ \\
\hline & $(0.126)$ & $(0.170)$ & $(0.189)$ & $(0.055)$ & $(0.208)$ & $(0.071)$ \\
\hline \multirow[t]{2}{*}{ Public organization } & -0.179 & 0.183 & 0.048 & -0.301 & $-0.418 * * *$ & $-0.263 * * *$ \\
\hline & $(0.244)$ & $(0.181)$ & $(0.107)$ & $(0.213)$ & $(0.128)$ & $(0.058)$ \\
\hline \multirow[t]{2}{*}{ Local business organization } & $0.472 * * *$ & 0.253 & 0.163 & $0.246 * * *$ & 0.002 & $0.931 * * *$ \\
\hline & $(0.143)$ & $(0.210)$ & $(0.153)$ & $(0.072)$ & $(0.197)$ & $(0.059)$ \\
\hline
\end{tabular}




\begin{tabular}{|c|c|c|c|c|c|c|}
\hline \multirow{2}{*}{ Probit (Marginal Effects) } & $(1)$ & (2) & (3) & (4) & $(5)$ & (6) \\
\hline & \multicolumn{3}{|c|}{ MNCs } & \multicolumn{3}{|c|}{ Local Enterprises } \\
\hline Dependent variables: Yes (1) vs No (0) & $\begin{array}{l}\text { Significant } \\
\text { Improvement of } \\
\text { an existing } \\
\text { product }\end{array}$ & $\begin{array}{l}\text { New product } \\
\text { Based on the } \\
\text { existing } \\
\text { technologies }\end{array}$ & $\begin{array}{l}\text { New product } \\
\text { based on new } \\
\text { technologies }\end{array}$ & $\begin{array}{l}\text { Significant } \\
\text { Improvement of } \\
\text { an existing } \\
\text { product }\end{array}$ & $\begin{array}{l}\text { New product } \\
\text { based on the } \\
\text { existing } \\
\text { technologies }\end{array}$ & $\begin{array}{l}\text { New product } \\
\text { based on new } \\
\text { technologies }\end{array}$ \\
\hline \multirow{2}{*}{ University/ Public Research Institute } & -0.281 & -0.170 & -0.062 & 0.073 & $0.483 * * *$ & 0.396 \\
\hline & $(0.241)$ & $(0.181)$ & $(0.049)$ & $(0.178)$ & $(0.165)$ & $(0.276)$ \\
\hline \multirow[t]{2}{*}{$\mathrm{R} \& \mathrm{D}$} & $0.293^{* *}$ & 0.089 & 0.046 & -0.099 & -0.106 & -0.099 \\
\hline & $(0.122)$ & $(0.132)$ & $(0.075)$ & $(0.085)$ & $(0.107)$ & $(0.080)$ \\
\hline Country controls & Yes & Yes & Yes & Yes & Yes & Yes \\
\hline Establishment size controls & Yes & Yes & Yes & Yes & Yes & Yes \\
\hline Industry controls & Yes & Yes & Yes & Yes & Yes & Yes \\
\hline $\mathrm{N}$ & 113 & 121 & 115 & 149 & 148 & 129 \\
\hline $\mathrm{R} 2$ & 0.350 & 0.238 & 0.375 & 0.443 & 0.268 & 0.310 \\
\hline
\end{tabular}


In summary, each external resource, including the vertical supply chain and local alliances, has a different impact on innovation. First, a firm is not likely to improve existing goods or introduce new goods if the firm sold the product(s) to MNCs or JVs. Second, contrary to this finding, a firm is likely to improve existing goods or introduce new goods if the firm bought intermediate inputs from MNCs or JVs. Third, the positive impacts of local alliances with public business organizations or universities on product innovation are sizable, compared with the impacts of vertical production linkages,

\section{Diagnostics: incoming knowledge from external sources}

However many previous works, and this paper, have asked whether and to what extent external resources affect product improvement and product innovation (see Tables 4 and 5), we have yet to understand the underlying mechanism that determines which type of technology transfer is effective. We have not shown how firms absorb incoming knowledge spillovers from each linkage and alliance. To seek insight in this area, this paper also tries to demonstrate an anatomy of technology transfer and innovation using the direct information about eight different types of incoming knowledge from production or alliance partners as follows.

\section{Market}

2. Human Resources

3. Quality Control

4. Product development/Model change

5. Claims

6. Process technology

7. Product technology

8. Material/Parts technologies

We surveyed the sample firms' eight types of incoming knowledge against eight different types of external sources of new technologies and information related to 
upgrading. Table 6 presents the types and frequency of incoming knowledge by eight different external sources. Multiple answers are permitted. For example, local customers and buyers or trading companies mainly provide market information: $57.1 \%$ of firms answered that they drew market information from their local customers, $52.4 \%$ of firms acquired market information from local business organizations, and $51.7 \%$ of firms drew market information from their buyers or trading companies. We can summarize the other main features of the relationships between types of incoming knowledge and different types of external sources as follows: (1) firms are likely to acquire human resources information from universities and public research institutes; (2) firms tend to learn about quality control from local customers, MNC/JV customers or suppliers, and buyers or trading companies; (3) firms are also likely to get information relating to product development/model change from their suppliers as well as local customers and $\mathrm{MNC} / \mathrm{JV}$ customers; (4) firms receive claims from local customers; (5) firms receive information about process and product technology from their nearby suppliers, their nearby customers, and their MNC/JV customers; (6) firms tend to get information concerning material/parts technology from their nearby suppliers.

In sum, manufacturers in South East Asia mainly depend on their production partners rather than non-production partners such as public or business organizations, and universities. Customers or suppliers nearby play an important role in providing several types of information. MNC/JV customers and suppliers are also key players in technology transfer to firms in South East Asia. 
Table 6: Types and frequency of incoming knowledge by eight different external sources (Multiple answers are permitted)

\section{(1)}

(2)

(3)

(4)

(5)

(6)

(7)

(8)
Buyer or

trading

company
Local Local MNC/JV MNC/JV

customer supplier customer supplier
University/ Public

Research Institute

Types of incoming knowledge

Market

0.51

0.149

0.385

0.317

0.228

0.219

0.128

0.396

Material/Parts technologies

Source: ERIA Establishment Survey, 2010

\begin{tabular}{llllllll}
517 & 0.571 & 0.429 & 0.485 & 0.345 & 0.105 & 0.524 & 0.138 \\
149 & 0.268 & 0.280 & 0.128 & 0.070 & 0.212 & 0.287 & 0.427 \\
385 & 0.615 & 0.245 & 0.462 & 0.450 & 0.319 & 0.352 & 0.082 \\
317 & 0.443 & 0.378 & 0.485 & 0.380 & 0.240 & 0.163 & 0.152 \\
228 & 0.350 & 0.347 & 0.364 & 0.294 & 0.322 & 0.131 & 0.198 \\
128 & 0.394 & 0.380 & 0.429 & 0.289 & 0.270 & 0.156 & 0.177 \\
396 & 0.382 & 0.387 & 0.366 & 0.366 & 0.266 & 0.154 & 0.163 \\
\hline
\end{tabular}


In this section, this paper provides a general understanding of the relationship between innovation and incoming knowledge spillovers. As we have seen in the previous section, there are three levels of firm-level innovation which increase in difficulty on a step-by-step basis, ranging from a relatively easy investment (improvement of existing products) to relatively difficult or risky investments (the introduction of new products based on new technologies). This paper uses that these incoming knowledge spillovers as set of explanatory variables to explain the ordered characteristics of innovation. Thus, we run following Ordered Probit Model by different types of external resources:

$$
y_{i}^{*}=\alpha+\beta T_{i}+\gamma x_{i}+u_{i}
$$

where dependent variable $y$ means the three different types of binary outcome of product innovation for each firm $i$ which equals to one if each firm (1) improves existing products, (2) introduces new products based on existing technologies, (3) introduces new products based on new technologies. Explanatory variable $T$ is a vector which captures eight different incoming knowledge spillovers listed above. This is also a proxy of type of technology transfer from vertical linkages with production partners, or alliances with public bodies. We also control firm-level absorptive capacity $x$ and a cross-sectional error term is shown by $u$.

This paper interprets the estimated coefficient of $T$ as the degree of firm-level technology which can transfer incoming knowledge spillovers from external sources to step-by-step innovation. Table 7 presents the estimated coefficient of $T$ and Columns 1 to 8 show the impacts of incoming knowledge spillovers from eight different external sources. It is readily apparent from Table 7 that the incoming knowledge spillovers with significant impacts are quite different depending on the external source. Column 1 of Table 7 shows that a buyer or trading company's quality control is the most important channel for achievement of the different levels of product innovation for firms selling their products to buyers or trading companies. Column 2 of Table 7 shows that product development/model change by local customers is most important channel for product innovation if a firm sold its existing product to local enterprises. Column 3 of Table 7 shows that claim management by local suppliers is the most important kind of 
incoming knowledge when a firm buys intermediate inputs from local enterprises.

Column 4 of Table 7 provides an interesting contrast between two types of incoming knowledge, between keeping quality of existing product and developing new product lineup. Claim management by downstream MNC customers does not stimulate product innovation at all. This reflects firm-level risk management which deals with maladjustment or malpractice in existing products and concentrates internal resources to manage claims. Thus, it is likely that firms will not introduce new goods when they receive claim management information from an $\mathrm{MNC}$ customer. On the other hand, incoming knowledge of production technology from MNC customers have positive impacts on product innovation. Column 5 of Table 7 also provides a clear contrast between securing product quality and achieving product development. That is, incoming quality control knowledge from local suppliers negatively affects product innovation. On the other hand, incoming product development/model change by local suppliers has a positive and significant impact on product innovation.

Finally, Columns 6 to 8 show the results of alliances with public organizations, local business organizations, and universities respectively. First, it is reasonable that there are no channels related to manufacturing technologies and thus incoming human resource knowledge is the most important channel of product innovation from alliances with public organizations (Column 6). Second, if firms collaborate with local business organizations, then the incoming human resource knowledge and product technology have negative impacts, while incoming knowledge about materials/parts technologies has a positive impact on product innovation (Column 7). Third, incoming knowledge about product technologies from universities can stimulate product innovation. But incoming knowledge about product development/model changes and materials/parts related technologies from universities have a negative impact on product innovation (Column 8). 
Table 7: Step-by-step product innovation is differently explained by incoming knowledge from eight different types of external sources

\begin{tabular}{|c|c|c|c|c|c|c|c|c|}
\hline \multirow[t]{2}{*}{ Ordered Probit } & \multicolumn{8}{|c|}{ Dependent variable: Product innovation } \\
\hline & $(1)$ & $(2)$ & (3) & (4) & $(5)$ & $(6)$ & (7) & $(8)$ \\
\hline $\begin{array}{l}\text { Incoming knowledge } \\
\text { from: }\end{array}$ & $\begin{array}{l}\text { Buyer or trading } \\
\text { company }\end{array}$ & $\begin{array}{l}\text { Local } \\
\text { customer }\end{array}$ & $\begin{array}{l}\text { Local } \\
\text { supplier }\end{array}$ & $\begin{array}{l}\mathrm{MNC} / \mathrm{JV} \\
\text { customer }\end{array}$ & $\begin{array}{l}\text { MNC/JV } \\
\text { supplier }\end{array}$ & $\begin{array}{l}\text { Public } \\
\text { organization }\end{array}$ & $\begin{array}{l}\text { Local business } \\
\text { organization }\end{array}$ & $\begin{array}{l}\text { University/ Public Research } \\
\text { Institute }\end{array}$ \\
\hline \multicolumn{9}{|l|}{$\begin{array}{l}\text { Types of incoming } \\
\text { knowledge }\end{array}$} \\
\hline Market & $\begin{array}{l}-0.138 \\
(0.184)\end{array}$ & $\begin{array}{c}0.045 \\
(0.186)\end{array}$ & $\begin{array}{c}0.152 \\
(0.195)\end{array}$ & $\begin{array}{c}0.098 \\
(0.222)\end{array}$ & $\begin{array}{c}0.052 \\
(0.249)\end{array}$ & $\begin{array}{l}-0.050 \\
(0.207)\end{array}$ & $\begin{array}{l}-0.004 \\
(0.246)\end{array}$ & $\begin{array}{c}0.131 \\
(0.204)\end{array}$ \\
\hline Human Resources & $\begin{array}{l}-0.155 \\
(0.192)\end{array}$ & $\begin{array}{c}0.267 \\
(0.179)\end{array}$ & $\begin{array}{l}-0.120 \\
(0.164)\end{array}$ & $\begin{array}{c}0.029 \\
(0.227)\end{array}$ & $\begin{array}{l}-0.013 \\
(0.204)\end{array}$ & $\begin{array}{l}0.372^{*} \\
(0.197)\end{array}$ & $\begin{array}{c}-0.399 * * \\
(0.169)\end{array}$ & $\begin{array}{l}-0.037 \\
(0.180)\end{array}$ \\
\hline Quality Control & $\begin{array}{l}0.281^{*} \\
(0.168)\end{array}$ & $\begin{array}{l}-0.223 \\
(0.183)\end{array}$ & $\begin{array}{l}-0.051 \\
(0.173)\end{array}$ & $\begin{array}{c}0.048 \\
(0.235)\end{array}$ & $\begin{array}{l}-0.360^{*} \\
(0.199)\end{array}$ & $\begin{array}{l}-0.515 \\
(0.350)\end{array}$ & $\begin{array}{l}-0.158 \\
(0.252)\end{array}$ & $\begin{array}{c}0.311 \\
(0.242)\end{array}$ \\
\hline $\begin{array}{l}\text { Product } \\
\text { development/Model } \\
\text { change }\end{array}$ & $\begin{array}{l}-0.080 \\
(0.172)\end{array}$ & $\begin{array}{l}0.304 * \\
(0.166)\end{array}$ & $\begin{array}{c}0.258 \\
(0.222)\end{array}$ & $\begin{array}{c}0.159 \\
(0.187)\end{array}$ & $\begin{array}{l}0.396^{*} \\
(0.231)\end{array}$ & $\begin{array}{c}0.371 \\
(0.693)\end{array}$ & $\begin{array}{l}0.448 * * \\
(0.197)\end{array}$ & $\begin{array}{l}-0.535^{* * *} \\
(0.200)\end{array}$ \\
\hline Claim & $\begin{array}{l}-0.152 \\
(0.194)\end{array}$ & $\begin{array}{c}0.085 \\
(0.152)\end{array}$ & $\begin{array}{l}0.299^{*} \\
(0.175)\end{array}$ & $\begin{array}{c}-0.569 * * * \\
(0.203)\end{array}$ & $\begin{array}{c}0.196 \\
(0.212)\end{array}$ & $\begin{array}{l}-0.176 \\
(0.198)\end{array}$ & $\begin{array}{c}0.343 \\
(0.232)\end{array}$ & $\begin{array}{c}0.243 \\
(0.164)\end{array}$ \\
\hline Process technology & $\begin{array}{c}0.094 \\
(0.175)\end{array}$ & $\begin{array}{l}-0.229 \\
(0.197)\end{array}$ & $\begin{array}{c}0.068 \\
(0.243)\end{array}$ & $\begin{array}{c}0.069 \\
(0.239)\end{array}$ & $\begin{array}{l}-0.103 \\
(0.379)\end{array}$ & $\begin{array}{l}-0.444 \\
(0.409)\end{array}$ & $\begin{array}{c}0.132 \\
(0.221)\end{array}$ & $\begin{array}{l}-0.282 \\
(0.189)\end{array}$ \\
\hline Product technology & $\begin{array}{c}0.131 \\
(0.230)\end{array}$ & $\begin{array}{c}0.193 \\
(0.143)\end{array}$ & $\begin{array}{c}0.235 \\
(0.297)\end{array}$ & $\begin{array}{l}0.530^{* *} \\
(0.231)\end{array}$ & $\begin{array}{c}0.254 \\
(0.234)\end{array}$ & $\begin{array}{c}0.335 \\
(0.478)\end{array}$ & $\begin{array}{c}-0.658^{* * * *} \\
(0.209)\end{array}$ & $\begin{array}{l}0.403^{*} \\
(0.206)\end{array}$ \\
\hline Material/Parts technologies & $\begin{array}{c}0.021 \\
(0.172)\end{array}$ & $\begin{array}{c}0.267 \\
(0.164)\end{array}$ & $\begin{array}{l}-0.080 \\
(0.207)\end{array}$ & $\begin{array}{c}0.372 \\
(0.285)\end{array}$ & $\begin{array}{c}0.071 \\
(0.272)\end{array}$ & $\begin{array}{c}0.091 \\
(0.338)\end{array}$ & $\begin{array}{l}0.388 * * \\
(0.188)\end{array}$ & $\begin{array}{l}-0.363 * \\
(0.192)\end{array}$ \\
\hline $\mathrm{R} \& \mathrm{D}$ & $\begin{array}{c}0.052 \\
(0.156)\end{array}$ & $\begin{array}{l}-0.011 \\
(0.158)\end{array}$ & $\begin{array}{c}0.078 \\
(0.155)\end{array}$ & $\begin{array}{l}-0.062 \\
(0.167)\end{array}$ & $\begin{array}{c}0.022 \\
(0.156)\end{array}$ & $\begin{array}{c}0.012 \\
(0.157)\end{array}$ & $\begin{array}{c}0.146 \\
(0.162)\end{array}$ & $\begin{array}{c}0.018 \\
(0.158)\end{array}$ \\
\hline
\end{tabular}




\begin{tabular}{|c|c|c|c|c|c|c|c|c|}
\hline \multirow[t]{2}{*}{ Ordered Probit } & \multicolumn{8}{|c|}{ Dependent variable: Product innovation } \\
\hline & (1) & (2) & (3) & (4) & (5) & $(6)$ & (7) & (8) \\
\hline $\begin{array}{l}\text { Incoming knowledge } \\
\text { from: }\end{array}$ & $\begin{array}{l}\text { Buyer or trading } \\
\text { company }\end{array}$ & $\begin{array}{l}\text { Local } \\
\text { customer }\end{array}$ & $\begin{array}{l}\text { Local } \\
\text { supplier }\end{array}$ & $\begin{array}{l}\mathrm{MNC} / \mathrm{JV} \\
\text { customer }\end{array}$ & $\begin{array}{l}\mathrm{MNC} / \mathrm{JV} \\
\text { supplier }\end{array}$ & $\begin{array}{l}\text { Public } \\
\text { organization }\end{array}$ & $\begin{array}{l}\text { Local business } \\
\text { organization }\end{array}$ & $\begin{array}{l}\text { University/ Public Research } \\
\text { Institute }\end{array}$ \\
\hline \multirow[t]{2}{*}{$100 \%$ locally owned } & 0.047 & 0.005 & 0.001 & 0.014 & 0.018 & 0.013 & 0.053 & -0.046 \\
\hline & $(0.147)$ & $(0.146)$ & $(0.144)$ & $(0.157)$ & $(0.149)$ & $(0.151)$ & $(0.146)$ & $(0.154)$ \\
\hline Country controls & Yes & Yes & Yes & Yes & Yes & Yes & Yes & Yes \\
\hline Establishment size controls & Yes & Yes & Yes & Yes & Yes & Yes & Yes & Yes \\
\hline Industry controls & Yes & Yes & Yes & Yes & Yes & Yes & Yes & Yes \\
\hline \multicolumn{9}{|l|}{ Constant } \\
\hline \multirow[t]{2}{*}{ cut1 } & 0.173 & 0.294 & 0.321 & 0.342 & 0.126 & 0.323 & 0.053 & 0.242 \\
\hline & $(0.381)$ & $(0.384)$ & $(0.380)$ & $(0.383)$ & $(0.364)$ & $(0.374)$ & $(0.395)$ & $(0.380)$ \\
\hline \multirow[t]{2}{*}{ cut2 } & $0.806^{* *}$ & $0.944 * *$ & $0.963 * *$ & $1.001 * * *$ & $0.766^{* *}$ & $0.960 * *$ & $0.713 *$ & $0.890^{* *}$ \\
\hline & $(0.383)$ & $(0.387)$ & $(0.384)$ & $(0.385)$ & $(0.364)$ & $(0.374)$ & $(0.396)$ & $(0.380)$ \\
\hline \multirow[t]{2}{*}{ cut3 } & $1.373 * * *$ & $1.521 * * *$ & $1.535^{* * *}$ & $1.583 * * *$ & $1.337 * * *$ & $1.528 * * *$ & $1.299 * * *$ & $1.465^{* * *}$ \\
\hline & $(0.387)$ & $(0.389)$ & $(0.388)$ & $(0.387)$ & $(0.366)$ & $(0.377)$ & $(0.396)$ & $(0.380)$ \\
\hline $\mathrm{N}$ & 286 & 286 & 286 & 286 & 286 & 286 & 286 & 286 \\
\hline $\mathrm{R} 2$ & 0.0385 & 0.0522 & 0.0453 & 0.0580 & 0.0455 & 0.0408 & 0.0604 & 0.0529 \\
\hline
\end{tabular}

Source: ERIA Establishment Survey, 2010 
This section examines the anatomy of the relationship between external sources and industry upgrading. More specifically we ask: "what types of incoming knowledge spillovers from partners could affect the step-by-step nature of product innovation?" We analyze eight different external sources and eight types of incoming knowledge through knowledge exchanges with production partners or strategic alliances with public organizations or universities. We find the following three conclusions. First, each external source has its own specific advantage. The types of effective incoming knowledge spillovers are quite different between the external sources. Second, there is an interesting contrast between two types of incoming knowledge in relation to the firm's decision to either maintain the quality of existing products or to develop new a product lineup. Third, both vertical production linkages and alliances with public organizations or universities seem to offer different type of effective outgoing knowledge.

\section{Discussion and conclusion}

This paper is an example of an econometric case study of the impacts of technology transfer across upstream and downstream industries in the context of East Asian production networks. To do this the paper examines the role of external resources in influencing firm-level product innovation in auto-related industries located in South East Asia. More specifically, we ask two questions which are specific to auto-related manufacturing enterprises in Indonesia, Thailand, the Philippines, and Vietnam. First: "what is the extent of technology transfer from vertical production networks and linkages with public organizations and/or universities and industry bodies (UILs) in the areas of product improvement and development?" Second: "what types of incoming knowledge spillovers lead to technology transfer from external sources? These two questions help us to test the hypothesis that a specialized supplier network is a source of competitive advantage to the auto industry (Dyer 1996, 1997) in the mixed situation of inter-industrial linkages and university-industry linkages in developing economies. Our answer here is quite simple: knowledge derived from alliances with public organizations or universities, and from vertical linkages, offer different degrees of 
effectiveness in the promotion of product innovation.

In a sample of firms active in automotive-related industries in ASEAN, including metal products, plastics products, and rubber products, we found that greater knowledge sharing on the part of MNC customers in foreign countries resulted in a lower propensity for product innovation. This reflects the fact that that the ASEAN supplier's manufacturing process and capabilities are devoted to their foreign MNC customer. In fact, we also found that incoming knowledge from the MNC customer about the management of claims arising from faulty existing products especially explained the lower propensity of product innovation for ASEAN firms. This clear evidence shows a trade-off between maintaining current manufacturing operations and developing new products. This is consistent with our finding on the negative relationship between Just-in-time (JIT) organization with customers and product innovation, and the positive relationship between JIT organization and process improvement (See Machikita and Ueki, 2011b).

We found that production linkages with MNC suppliers in foreign countries resulted in a higher propensity for product innovation. We also found that incoming knowledge from MNC suppliers about quality controls explained the lower propensity for product innovation. This also supports the evidence that there exists a trade-off between maintaining existing manufacturing operations and new product development. This trade-off is also consistent with the theoretical framework of Berliant and Fujita (2008, 2009).

Strategic alliances with public organizations, local business organizations, and universities also play an important role in product innovation. Empirical results suggest that the innovation impacts of such alliances are significant, and sizable compared to the innovation impacts of vertical linkages. We found that alliances and vertical linkages offered different effectiveness's of knowledge in the case of product innovation. These two types of external sources could be complementing each other. Increased knowledge sharing with production partners (especially MNCs) has caused a significant technological upgrading and has led to product innovation in ASEAN firms. There is not, however, a straightforward relationship between maintaining the quality of existing products and developing new products. 


\section{References}

Aitken, B, J., and A. E. Harrison. (1999) Do Domestic Firms Benefit from Direct Foreign Investment? Evidence from Venezuela, American Economic Review, 89(3):605-618.

Bekkers, R., and Bodas Freitas, I. M., (2008) Analysing Knowledge Transfer Channels between Universities and Industry: To What Degree Do Sectors also Matter?, Research Policy, 37: 1837-53.

Bercovitz, J., and M. Feldman, (2008) Academic Entrepreneurs: Organizational Change at the Individual Level. Organization Science, 19(1): 69-89.

Bercovitz, J., and M. P. Feldman, (2006) Entrepreneurial Universities and Technology Transfer: A Conceptual Framework for Understanding Knowledge-Based Economic Development. Journal of Technology Transfer, 31(1): 175-188.

Bercovitz, J. E. L., and M. P. Feldman, (2007) Fishing upstream: Firm innovation strategy and university research alliances. Research Policy, 36(7): 930-948.

Bercovitz, J., and M. Feldman., (2011) The mechanisms of collaboration in inventive teams: Composition, social networks, and geography. Research Policy, 40(1): 81-93.

Berliant, M., and Fujita, M., (2008) Knowledge Creation as a Square Dance on the Hilbert Cube. International Economic Review, 49 (4), 1251-1268.

Berliant, M., and Fujita, M., (2009) Dynamics of Knowledge Creation and Transfer: The Two Person Case. International Journal of Economic Theory, 5, 155-179.

Blalock, G. and Gertler, P. J., (2008) Welfare gains from Foreign Direct Investment through technology transfer to local suppliers. Journal of International Economics, 74, 402-421.

Bresnahan, T. F., Brynjolfsson, E., and Hitt, L. M., (2002) Information Technology, Workplace Organization, And The Demand For Skilled Labor: Firm-Level Evidence. The Quarterly Journal of Economics, 117(1), 339-376.

Cassiman, B., and Veugelers, R., (2002) R\&D Cooperation and Spillovers: Some Empirical Evidence from Belgium. American Economic Review, 92(4): 1169-1184.

Cassiman, B., and Veugelers, R., (2006) In Search of Complementarity in Innovation Strategy: Internal R\&D and External Knowledge Acquisition. Management Science, 52(1): 68-82.

Conley, T., and Udry, C., (2010) Learning about a New Technology: Pineapple in Ghana. American Economic Review, 100(1), pp. 35-69.

Dyer, J, H. and Chu, W., (2000) The Determinants of Trust in Supplier-Automaker Relationships in the U.S., Japan, and Korea. Journal of International Business Studies, 31(2), 259-285. 
Dyer, J, H. and Chu, W., (2003) The Role of Trustworthiness in Reducing Transaction Costs and Improving Performance: Empirical Evidence from the United States, Japan, and Korea. Organization Science, 14(1), 57-68.

Dyer, J, H. and Nobeoka, K., (2000) Creating and Managing a High-Performance Knowledge-Sharing Network: The Toyota Case. Strategic Management Journal (Special Issue: Strategic Networks), 21(3), 345-367.

Dyer, J, H. and Singh, H., (1998) The Relational View: Cooperative Strategy and Sources of Interorganizational Competitive Advantage. The Academy of Management Review, 23(4), 660-679.

Dyer, J, H., (1996) Specialized Supplier Networks as a Source of Competitive Advantage: Evidence from the Auto Industry. Strategic Management Journal, 17(4), 271-291.

Dyer, J, H., (1997) Effective Inter-firm Collaboration: How Firms Minimize Transaction Costs and Maximize Transaction Value. Strategic Management Journal, 18(7), 535-556.

Eom, B., and Lee, K., (2010) Determinants of industry-academy linkages and, their impact on firm performance: The case of Korea as a latecomer in knowledge industrialization. Research Policy, 39(5): 625-639.

Frenz, M., and Ietto-Gilles, G., (2009) The Impact on Innovation Performance of Different Sources of Knowledge: Evidence from the UK Community Innovation Survey. Research Policy, 38: 1125-1135.

Hortacsu, A., and Syverson, C., (2009) Why do Firms Own Production Chains? mimeo.

Hsieh, C, T., and Klenow, P, J., (2009) Misallocation and Manufacturing TFP in China and India. The Quarterly Journal of Economics, 124(4), 1403-1448.

Intarakumnerd, P., and Fujita, M., (2008) Coping with a Giant: Challenges and Opportunities for Thai and Vietnamese Motorcycle Industry from China. Science Technology Society, 13(1), 35-60.

Javorcik, B., (2004) Does Foreign Direct Investment Increase the Productivity of Domestic Firms? In Search of Spillovers through Backward Linkages. American Economic Review, 94, 605-627.

Kroll, H., and Liefner, I., (2008) Spin-off Enterprises as a Means of Technology Commercialization in a Transforming Economy- Evidence from Three Universities in China. Technovation, 28(5): 298-313.

Laursen, K., and Salter, A., (2004) Searching high and low: what types of firms use universities as a source of innovation? Research Policy, 33(8): 1201-1215.

Lundvall, B.-Å., (1985) Product Innovation and User-Producer Interaction, Aalborg: Aalborg University Press.

Lundvall, B.-Å., (1988) Innovation as an Interactive Process - from User-Producer Interaction to National Systems of Innovation, in Dosi, G. m.fl. (eds.): Technology and Economic Theory, London: Pinter Publishers. 
Machikita, T., and Y. Ueki, (2011a) Innovation in Linked and Non-linked Firms: Effects of Variety of Linkages in East Asia. International Journal of Institutions and Economies, 3(1), 77-102.

Machikita, T., and Y. Ueki, (2011b) The Impacts of Face-to-face and Frequent Interactions on Innovation: Upstream-Downstream Relations. International Journal of Institutions and Economies, 3(3), 519-548.

Mansfield, E., (1991) Academic Research and Industrial Innovation. Research Policy, 20(1): $1-12$.

Mansfield, E., (1998) Academic Research and Industrial Innovation: An Update of Empirical Findings. Research Policy 26 (7-8): 773-6.

Monjon, S., and Waelbroeck, P., (2003) Assessing Spillovers from Universities to Firms: Evidence from French Firm-level Data. International Journal of Industrial Organization, 21(9): 1255-70.

Nobeoka, K., Dyer, J,H., and A. Madhok, (2002) The Influence of Customer Scope on Supplier Learning and Performance in the Japanese Automobile Industry. Journal of International Business Studies, 33(4), 717-736.

Polanyi, M., (1966) The Logic of Tacit Inference, Philosophy, The Journal of the Royal Institute of Philosophy, 41, No.155, 1-18.

Polanyi, M., (1966, 2009) The Tacit Dimension, University of Chicago Press.

Salter, A. J., and Martin, B. R., 2001, The Economic Benefits of Publicly Funded Basic Research: A Critical Review. Research Policy, 30(3): 509-39.

Syverson, C., (2011) What Determines Productivity? Journal of Economic Literature, 49(2): 326-65.

Teece, D. J., (2009) Dynamic capabilities and strategic management: organization for innovation and growth, Oxford University Press.

Vega Jurad, J., Gutiereez-Gracia, A., Fernandez-de-Lucio, I., and Manjarres-Henriquez, L., (2008) The Effect of External and Internal Factors on Firm's Product Innovation. Research Policy, 37: 616-632.

von Hippel, E. (1986) Lead users: a source of novel product concepts. Management Science, 32(7), 791-805.

von Hippel, E. (1988) The sources of innovation, Oxford University Press.

von Hippel, E. (2005) Democratizing innovation, MIT Press. 
ERIA Discussion Paper Series

\begin{tabular}{|c|c|c|c|}
\hline No. & Author(s) & Title & Year \\
\hline 2011-08 & $\begin{array}{l}\text { Tomohiro MACHIKITA } \\
\text { and Yasushi UEKI }\end{array}$ & $\begin{array}{l}\text { Impacts of Incoming Knowledge on Product Innovation: } \\
\text { Econometric Case Studies of Technology Transfer of } \\
\text { Auto-related Industries in Developing Economies }\end{array}$ & $\begin{array}{l}\text { Nov } \\
2011\end{array}$ \\
\hline \multirow{2}{*}{ 2011-07 } & \multirow[b]{2}{*}{ Yanrui WU } & Gas Market Integration: & Nov \\
\hline & & Global Trends and Implications for the EAS Region & 2011 \\
\hline \multirow{2}{*}{$2011-06$} & \multirow[b]{2}{*}{ Philip Andrews-SPEED } & Energy Market Integration in East Asia: & Nov \\
\hline & & A Regional Public Goods Approach & 2011 \\
\hline \multirow{2}{*}{$2011-05$} & Yu SHENG, & $\begin{array}{l}\text { Energy Market Integration and Economic } \\
\text { Convergence: }\end{array}$ & \multirow{2}{*}{$\begin{array}{r}\text { Oct } \\
2011\end{array}$} \\
\hline & Xunpeng SHI & Implications for East Asia & \\
\hline \multirow[b]{2}{*}{$2011-04$} & Sang-Hyop LEE, Andrew & $\begin{array}{l}\text { Why Does Population Aging Matter So Much for } \\
\text { Asia? }\end{array}$ & \multirow{2}{*}{$\begin{array}{l}\text { Aug } \\
2011\end{array}$} \\
\hline & $\begin{array}{l}\text { MASON, and Donghyun } \\
\text { PARK }\end{array}$ & $\begin{array}{l}\text { Population Aging, Economic Security and } \\
\text { Economic Growth in Asia }\end{array}$ & \\
\hline $2011-03$ & $\begin{array}{l}\text { Xunpeng SHI, } \\
\text { Shinichi GOTO }\end{array}$ & $\begin{array}{l}\text { Harmonizing Biodiesel Fuel Standards in East Asia: } \\
\text { Current Status, Challenges and the Way Forward }\end{array}$ & $\begin{array}{l}\text { May } \\
2011\end{array}$ \\
\hline 2011-02 & Hikari ISHIDO & $\begin{array}{l}\text { Liberalization of Trade in Services under ASEAN }+n \text { : } \\
\text { A Mapping Exercise }\end{array}$ & $\begin{array}{l}\text { May } \\
2011\end{array}$ \\
\hline 2011-01 & $\begin{array}{l}\text { Kuo-I CHANG, Kazunobu } \\
\text { HAYAKAWA } \\
\text { Toshiyuki MATSUURA }\end{array}$ & $\begin{array}{l}\text { Location Choice of Multinational Enterprises in } \\
\text { China: Comparison between Japan and Taiwan }\end{array}$ & $\begin{array}{l}\text { Mar } \\
2011\end{array}$ \\
\hline $2010-11$ & $\begin{array}{l}\text { Charles HARVIE, } \\
\text { Dionisius NARJOKO, } \\
\text { Sothea OUM }\end{array}$ & $\begin{array}{l}\text { Firm Characteristic Determinants of SME } \\
\text { Participation in Production Networks }\end{array}$ & $\begin{array}{c}\text { Oct } \\
2010\end{array}$ \\
\hline $2010-10$ & Mitsuyo ANDO & $\begin{array}{l}\text { Machinary Trade in East Asia, and the Global } \\
\text { Financial Crisis }\end{array}$ & $\begin{array}{l}\text { Oct } \\
2010\end{array}$ \\
\hline 2010-09 & $\begin{array}{l}\text { Fukunari KIMURA } \\
\text { Ayako OBASHI }\end{array}$ & $\begin{array}{l}\text { International Production Networks in Machinery } \\
\text { Industries: Structure and Its Evolution }\end{array}$ & $\begin{array}{c}\text { Sep } \\
2010\end{array}$ \\
\hline $2010-08$ & $\begin{array}{l}\text { Tomohiro MACHIKITA, } \\
\text { Shoichi MIYAHARA, } \\
\text { Masatsugu TSUJI, and } \\
\text { Yasushi UEKI }\end{array}$ & $\begin{array}{l}\text { Detecting Effective Knowledge Sources in Product } \\
\text { Innovation: Evidence from Local Firms and } \\
\text { MNCs/JVs in Southeast Asia }\end{array}$ & $\begin{array}{l}\text { Aug } \\
2010\end{array}$ \\
\hline 2010-07 & $\begin{array}{l}\text { Tomohiro MACHIKITA, } \\
\text { Masatsugu TSUJI, and } \\
\text { Yasushi UEKI }\end{array}$ & $\begin{array}{l}\text { How ICTs Raise Manufacturing Performance: } \\
\text { Firm-level Evidence in Southeast Asia }\end{array}$ & $\begin{array}{l}\text { Aug } \\
2010\end{array}$ \\
\hline
\end{tabular}




\begin{tabular}{|c|c|c|c|}
\hline $2010-06$ & Xunpeng SHI & $\begin{array}{l}\text { Carbon Footprint Labeling Activities in the East Asia } \\
\text { Summit Region: Spillover Effects to Less Developed } \\
\text { Countries }\end{array}$ & $\begin{array}{l}\text { July } \\
2010\end{array}$ \\
\hline $2010-05$ & $\begin{array}{l}\text { Kazunobu HAYAKAWA, } \\
\text { Fukunari KIMURA, and } \\
\text { Tomohiro MACHIKITA }\end{array}$ & $\begin{array}{l}\text { Firm-level Analysis of Globalization: A Survey of the } \\
\text { Eight Literatures }\end{array}$ & $\begin{array}{l}\text { Mar } \\
2010\end{array}$ \\
\hline $2010-04$ & $\begin{array}{l}\text { Tomohiro MACHIKITA } \\
\text { and Yasushi UEKI }\end{array}$ & $\begin{array}{l}\text { The Impacts of Face-to-face and Frequent } \\
\text { Interactions on Innovation: } \\
\text { Upstream-Downstream Relations }\end{array}$ & $\begin{array}{c}\text { Feb } \\
2010\end{array}$ \\
\hline $2010-03$ & $\begin{array}{l}\text { Tomohiro MACHIKITA } \\
\text { and Yasushi UEKI }\end{array}$ & $\begin{array}{l}\text { Innovation in Linked and Non-linked Firms: } \\
\text { Effects of Variety of Linkages in East Asia }\end{array}$ & $\begin{array}{c}\text { Feb } \\
2010\end{array}$ \\
\hline $2010-02$ & $\begin{array}{l}\text { Tomohiro MACHIKITA } \\
\text { and Yasushi UEKI }\end{array}$ & $\begin{array}{l}\text { Search-theoretic Approach to Securing New } \\
\text { Suppliers: Impacts of Geographic Proximity for } \\
\text { Importer and Non-importer }\end{array}$ & $\begin{array}{c}\text { Feb } \\
2010\end{array}$ \\
\hline $2010-01$ & $\begin{array}{l}\text { Tomohiro MACHIKITA } \\
\text { and Yasushi UEKI }\end{array}$ & $\begin{array}{l}\text { Spatial Architecture of the Production Networks in } \\
\text { Southeast Asia: } \\
\text { Empirical Evidence from Firm-level Data }\end{array}$ & $\begin{array}{l}\text { Feb } \\
2010\end{array}$ \\
\hline $2009-23$ & Dionisius NARJOKO & $\begin{array}{l}\text { Foreign Presence Spillovers and Firms' Export } \\
\text { Response: } \\
\text { Evidence from the Indonesian Manufacturing }\end{array}$ & $\begin{array}{l}\text { Nov } \\
2009\end{array}$ \\
\hline $2009-22$ & $\begin{array}{l}\text { Kazunobu HAYAKAWA, } \\
\text { Daisuke HIRATSUKA, } \\
\text { Kohei SHIINO, and } \\
\text { Seiya SUKEGAWA }\end{array}$ & Who Uses Free Trade Agreements? & $\begin{array}{l}\text { Nov } \\
2009\end{array}$ \\
\hline $2009-21$ & Ayako OBASHI & $\begin{array}{l}\text { Resiliency of Production Networks in Asia: } \\
\text { Evidence from the Asian Crisis }\end{array}$ & $\begin{array}{c}\text { Oct } \\
2009\end{array}$ \\
\hline $2009-20$ & $\begin{array}{l}\text { Mitsuyo ANDO and } \\
\text { Fukunari KIMURA }\end{array}$ & Fragmentation in East Asia: Further Evidence & $\begin{array}{c}\text { Oct } \\
2009 \\
\end{array}$ \\
\hline 2009-19 & Xunpeng SHI & $\begin{array}{l}\text { The Prospects for Coal: } \\
\text { Global Experience and Implications for Energy } \\
\text { Policy }\end{array}$ & $\begin{array}{l}\text { Sept } \\
2009\end{array}$ \\
\hline $2009-18$ & Sothea OUM & $\begin{array}{l}\text { Income Distribution and Poverty in a CGE } \\
\text { Framework: A Proposed Methodology }\end{array}$ & $\begin{array}{c}\text { Jun } \\
2009\end{array}$ \\
\hline $2009-17$ & $\begin{array}{l}\text { Erlinda M. MEDALLA } \\
\text { and Jenny BALBOA }\end{array}$ & $\begin{array}{l}\text { ASEAN Rules of Origin: } \\
\text { Lessons and Recommendations for the Best Practice }\end{array}$ & $\begin{array}{c}\text { Jun } \\
2009\end{array}$ \\
\hline $2009-16$ & Masami ISHIDA & Special Economic Zones and Economic Corridors & $\begin{array}{c}\text { Jun } \\
2009\end{array}$ \\
\hline $2009-15$ & Toshihiro KUDO & $\begin{array}{l}\text { Border Area Development in the GMS: } \\
\text { Turning the Periphery into the Center of Growth }\end{array}$ & $\begin{array}{l}\text { May } \\
2009\end{array}$ \\
\hline
\end{tabular}




\begin{tabular}{|c|c|c|c|}
\hline $2009-14$ & $\begin{array}{l}\text { Claire HOLLWEG and } \\
\text { Marn-Heong WONG }\end{array}$ & $\begin{array}{l}\text { Measuring Regulatory Restrictions in Logistics } \\
\text { Services }\end{array}$ & $\begin{array}{c}\text { Apr } \\
2009\end{array}$ \\
\hline $2009-13$ & Loreli C. De DIOS & Business View on Trade Facilitation & $\begin{array}{c}\text { Apr } \\
2009\end{array}$ \\
\hline $2009-12$ & $\begin{array}{l}\text { Patricia SOURDIN and } \\
\text { Richard POMFRET }\end{array}$ & Monitoring Trade Costs in Southeast Asia & $\begin{array}{c}\text { Apr } \\
2009\end{array}$ \\
\hline $2009-11$ & $\begin{array}{l}\text { Philippa DEE and } \\
\text { Huong DINH }\end{array}$ & $\begin{array}{l}\text { Barriers to Trade in Health and Financial Services in } \\
\text { ASEAN }\end{array}$ & $\begin{array}{c}\text { Apr } \\
2009\end{array}$ \\
\hline $2009-10$ & Sayuri SHIRAI & $\begin{array}{l}\text { The Impact of the US Subprime Mortgage Crisis on } \\
\text { the World and East Asia: Through Analyses of } \\
\text { Cross-border Capital Movements }\end{array}$ & $\begin{array}{c}\text { Apr } \\
2009\end{array}$ \\
\hline 2009-09 & $\begin{array}{l}\text { Mitsuyo ANDO and } \\
\text { Akie IRIYAMA }\end{array}$ & $\begin{array}{l}\text { International Production Networks and Export/Import } \\
\text { Responsiveness to Exchange Rates: } \\
\text { The Case of Japanese Manufacturing Firms }\end{array}$ & $\begin{array}{l}\text { Mar } \\
2009\end{array}$ \\
\hline $2009-08$ & $\begin{array}{l}\text { Archanun } \\
\text { KOHPAIBOON }\end{array}$ & $\begin{array}{l}\text { Vertical and Horizontal FDI Technology Spillovers: } \\
\text { Evidence from Thai Manufacturing }\end{array}$ & $\begin{array}{r}\text { Mar } \\
2009\end{array}$ \\
\hline 2009-07 & $\begin{array}{l}\text { Kazunobu HAYAKAWA, } \\
\text { Fukunari KIMURA, and } \\
\text { Toshiyuki MATSUURA }\end{array}$ & $\begin{array}{l}\text { Gains from Fragmentation at the Firm Level: } \\
\text { Evidence from Japanese Multinationals in East Asia }\end{array}$ & $\begin{array}{l}\text { Mar } \\
2009\end{array}$ \\
\hline 2009-06 & Dionisius A. NARJOKO & $\begin{array}{l}\text { Plant Entry in a More Liberalised Industrialisation } \\
\text { Process: An Experience of Indonesian } \\
\text { Manufacturing during the } 1990 \mathrm{~s}\end{array}$ & $\begin{array}{l}\text { Mar } \\
2009\end{array}$ \\
\hline $2009-05$ & $\begin{array}{l}\text { Kazunobu HAYAKAWA, } \\
\text { Fukunari KIMURA, and } \\
\text { Tomohiro MACHIKITA }\end{array}$ & Firm-level Analysis of Globalization: A Survey & $\begin{array}{l}\text { Mar } \\
2009\end{array}$ \\
\hline 2009-04 & $\begin{array}{l}\text { Chin Hee HAHN and } \\
\text { Chang-Gyun PARK }\end{array}$ & $\begin{array}{l}\text { Learning-by-exporting in Korean Manufacturing: } \\
\text { A Plant-level Analysis }\end{array}$ & $\begin{array}{l}\text { Mar } \\
2009\end{array}$ \\
\hline $2009-03$ & Ayako OBASHI & $\begin{array}{l}\text { Stability of Production Networks in East Asia: } \\
\text { Duration and Survival of Trade }\end{array}$ & $\begin{array}{l}\text { Mar } \\
2009\end{array}$ \\
\hline $2009-02$ & Fukunari KIMURA & $\begin{array}{l}\text { The Spatial Structure of Production/Distribution } \\
\text { Networks and Its Implication for Technology } \\
\text { Transfers and Spillovers }\end{array}$ & $\begin{array}{l}\text { Mar } \\
2009\end{array}$ \\
\hline $2009-01$ & $\begin{array}{l}\text { Fukunari KIMURA and } \\
\text { Ayako OBASHI }\end{array}$ & $\begin{array}{l}\text { International Production Networks: } \\
\text { Comparison between China and ASEAN }\end{array}$ & $\begin{array}{c}\text { Jan } \\
2009\end{array}$ \\
\hline $2008-03$ & $\begin{array}{l}\text { Kazunobu HAYAKAWA } \\
\text { and Fukunari KIMURA }\end{array}$ & $\begin{array}{l}\text { The Effect of Exchange Rate Volatility on } \\
\text { International Trade in East Asia }\end{array}$ & $\begin{array}{c}\text { Dec } \\
2008\end{array}$ \\
\hline 2008-02 & $\begin{array}{l}\text { Satoru KUMAGAI, } \\
\text { Toshitaka GOKAN, } \\
\text { Ikumo ISONO, and }\end{array}$ & $\begin{array}{l}\text { Predicting Long-Term Effects of Infrastructure } \\
\text { Development Projects in Continental South East } \\
\text { Asia: IDE Geographical Simulation Model }\end{array}$ & $\begin{array}{c}\text { Dec } \\
2008\end{array}$ \\
\hline
\end{tabular}


Souknilanh KEOLA

Kazunobu HAYAKAWA,

2008-01 Fukunari KIMURA, and

Firm-level Analysis of Globalization: A Survey

Dec

Tomohiro MACHIKITA

2008 